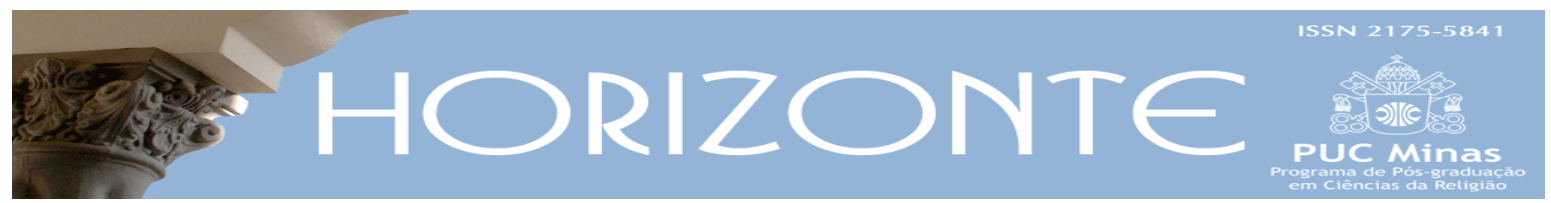

Dossiê: Fundamentalismos e Democracia - Artigo Original (c) (1)

\title{
Evangélicos e conservadorismo - afinidades eletivas: as novas configurações da democracia no Brasil
}

\author{
Evangelicals and conservatism - elective affinities: \\ the new configurations of democracy in Brazil
}

\author{
Paulo Gracino de Souza Junior*
}

Carlos Henrique Pereira de Souza**

\begin{abstract}
Resumo
Neste artigo partimos da hipótese de que a afinidade que atrai evangélicos e conservadorismo está muito mais ligada às condições discursivas que engendram os sujeitos e suas subjetividades, do que as características intrínsecas à teologia cristã ou, especificamente, evangélica pentecostal. Com isso não queremos dizer que conformações teológicas específicas não ensejaram discursos religiosos regressivos, que a maioria de nós classificaria como conservador. Assim, chamamos a atenção, tanto para o caráter relacional, posicional das identidades evangélicas, que engendram o discurso conservador, quanto para a base material deste discurso, ligando, portanto, sujeitos e formas de sujeição e subjetivação. Interessam-nos, as formas políticas em que se precipitarão os antagonismos articulados a partir dos grupos de identidade evangélica, bem como os deslocamentos na base material destes sujeitos, que possibilitam o engendramento de subjetividades atomizadas e refratárias a solidariedades coletivas exógenas a sua comunidade. Defenderemos que, embora evangélicos tenham ganhado relevo no espaço público por pautas reativas à ampliação de direitos de minorias, tais ações não se devem unicamente a aspectos intrínsecos à teologia pentecostal, ou ao seu caráter alienante ou irracional, mas, principalmente a forma como se posicionam no jogo político nacional, ou melhor, como se publicizaram, bem como a forma como o discurso de fundo conservador é acionado como estratégia de sobrevivência nas grandes cidades.
\end{abstract}

Palavras-chave: Conservadorismo pentecostal. Neoliberalismo. Política. Populismo.

\begin{abstract}
In this article we start from the hypothesis that the affinity that attracts evangelicals and conservatism is much more linked to the discursive conditions that engender subjects and their subjectivities, than the characteristics intrinsic to Christian theology or, specifically, evangelical pentecostal. By this we do not mean that specific theological formations did not give rise to regressive religious discourses, which most of us would classify as conservative. Thus, we call attention, both to the relational, positional character of the evangelical identities that engender the conservative discourse, and to the material basis of this discourse, linking, therefore, subjects and forms of subjection and subjectification. We are interested in the political forms in which the antagonisms articulated from the groups of evangelical identity will precipitate, as well as the dislocations in the material base of these subjects, which make it possible to engender atomized subjectivities that are refractory to collective solidarities exogenous to their community. We will defend that, although evangelicals have gained prominence in the public space due to reactive guidelines to the expansion of minority rights, such actions are not due solely to aspects intrinsic to Pentecostal theology, or to its alienating or irrational character, but mainly to the way position themselves in the national political game, or rather, as they were publicized, as well as the way in which the conservative discourse is triggered as a survival strategy in large cities.
\end{abstract}

Keywords: Pentecostal conservatism. Neoliberalism. Policy. Populismo.

Artigo submetido em 8 de agosto de 2020 e aprovado em 27 de dezembro de 2020.

* Doutor em Sociologia pela UERJ. Professor do IUPERJ/UCAM. País de origem: Brasil. E-mail: paulogracino@iuperj.br

** Doutor em Ciências Sociais pela UERJ. Professor da Secretaria de Estado de Educação do Rio de Janeiro. País de origem: Brasil. E-mail: chenrique27@gmail.com 


\section{Considerações iniciais}

Àquelas naturezas que, ao se encontrarem, se ligam de imediato, determinando-se mutuamente, chamamos 'afins'. Nos álcalis e ácidos essa afinidade é bastante evidente; embora sejam opostos e talvez justamente por isso, procuram-se e se agregam da maneira mais decidida, modificando-se e formando juntos um novo corpo. (GOETHE, 2008, p. 45).

Goethe publicou As afinidades eletivas no início do século XIX (1809). O título, baseado em um termo da química, era usado para descrever a tendência de uma substância ser atraída e combinar com outra de forma inexorável, porém, aplicado às relações humanas, insinua uma tendência, escolha, liberdade e eleição. Neste ponto, é a metáfora perfeita do romance que envolve um casal, Charlotte e Eduard, que se apaixona mutuamente por outro casal, Otille e Capitão Otto, que convidam para passar um tempo em sua residência no campo. Fiel ao seu tempo, Goethe crê na imprevisibilidade dos acontecimentos, que misturam o arbítrio da razão à irracionalidade das paixões. Assim, falando pela boca de Charlotte, Goethe deixa isso claro:

[...] todos os empreendimentos desse tipo são arriscados. Ninguém pode prever o que resultara deles. Essas novas circunstâncias podem gerar felicidade ou infelicidade, sem que possamos atribuí-las a nosso mérito ou a nossa culpa. Não me sinto suficientemente forte para contrariá-lo por mais tempo. Façamos a experiência! (GOETHE, 2008, p. 32).

Como sabemos é basicamente em Goethe que Weber se inspira para propor o conceito de afinidade eletiva para indicar uma tendência de afinidade entre imagens religiosas do mundo e formas de ética profissional (WEBER, 2004). Bem, é exatamente no sentido de uma afinidade que pensamos o imbricamento entre denominações religiosas do "espectro evangélico" ${ }^{1}$ e o

\footnotetext{
${ }^{1}$ Especificamente dentro da Sociologia das Religiões o termo evangélico, pentecostal, neopentecostal Pós-pentecostal foi alvo de grande debate desde que se estruturou um campo de estudos em torno do seu crescimento numérico em nosso país e sua influência pública (FRESTON, 1994; MARIANO, 1999 e SIEPIERSKI, 1997). No entanto, nas últimas décadas, o fluxo discursivo que se estabeleceu e se intensificou entre as diversas igrejas, inclusive do que foi categorizado como evangélicos de missão, levando ao comprometimento destas categorias, portanto, optamos pelo termo genérico evangélicos fazendo referência à denominação quando necessário. Tal expediente metodológico não significa um aplainamento das clivagens internas ao campo evangélico, sabemos que há inúmeras idiossincrasias entre o que se classifica genericamente como "evangélico" e que existe e se estrutura com certa força um campo político progressista, que nega o que genericamente tem sido classificado como pensamento conservador dentro do meio evangélico.
} 
conservadorismo/bolsonarismo, mesmo que a nossa ideia de sujeito esteja mais ligada ao sujeito foucaultiano que ao sujeito cognoscente das obras de Weber.

Assim, nossa principal hipótese é que a afinidade que atrai evangélicos e conservadorismo está muito mais ligada às condições discursivas que engendram os sujeitos e suas subjetividades do que a características intrínsecas à sua teologia. Com isso não queremos dizer que conformações teológicas específicas não ensejaram discursos religiosos regressivos, que a maioria de nós classificaria como conservador. Parafraseando Ruben César Fernandes (1985), é uma questão de conjuntura. Assim, chamamos a atenção tanto para o caráter relacional, posicional das identidades evangélicas, que fomentam o discurso conservador, quanto para a base material desse discurso, ligando, portanto, sujeitos e formas de sujeição e subjetivação.

Interessam-nos os antagonismos políticos ocasionados na cena nacional a partir de uma gramática religiosa conservadora em sua relação com o deslocamento na base material desses sujeitos, conformando subjetividades atomizadas e refratárias a solidariedades exógenas a sua comunidade, no que as contribuições de Foucault (2008) e Dardot e Laval serão centrais. Argumentaremos que, embora os evangélicos tenham ganhado relevo público por pautas reativas, baseadas em interpretações draconianas da bíblia, seu protagonismo está mais ligado ao modo como se posicionam em um jogo político que valoriza a hipertrofia do discurso moral e por oferecem estratégias de sobrevivência frente a violência e escassez vividas nas grandes cidades, ou seja, ao que Verónica Gago (2016) classificou, para outro contexto, de pragmática vitalista.

Antes de prosseguirmos, é importante salientar que a "onda conservadora" (ALMEIDA, 2019; BURITY, 2020) que aqui aparece com contornos religiosos, está longe de fazer de nossa pátria mãe gentil seu berço esplêndido, aparecendo reiteradas vezes na longa duração da moderna história das democracias ocidentais (ALONSO, 2018). De forma mais geral, as erupções conservadoras quase sempre 
aparecem ligadas a uma reação diante de processos de democratização, uma espécie de ódio à democracia, como bem aponta Jacques Rancière (2014).

Nessa esteira, a nova vaga de conservadorismo tem como combustível principal a ascensão de Novos Movimentos Sociais (SCOTT, 1990), que deslocaram de forma significativa o enfoque classista e a luta por igualdade para lutas com demandas mais plurais, como as políticas de gênero, igualdade civil da população LGBTQIA+, movimentos antirracistas, entre outros, invariavelmente concentradas no reconhecimento de direitos e de alteridade. Tais movimentos não só colocaram em xeque os antigos aparatos discursivos utilizados para sua interpretação, - o que gerou uma reação tanto social quanto acadêmica, na qual muitos estudiosos se mostraram reticentes em levar a sério o novo fenômeno - como também fraturaram a grande narrativa de estados democráticos ocidentais ao denunciarem seus pilares heteronormativos, patriarcais e majoritariamente brancos. Em muitos países, inclusive no Brasil, a atuação organizada de grupos que reivindicavam uma cidadania por reconhecimento de direitos (PRÁ e EPPING, 2018) levaram à emergência de um novo consenso jurídico-político que tem, ao menos no horizonte de possibilidades, a inclusão e o respeito às diferenças como condição para construção de uma sociedade mais justa e democrática, o que, por outro lado, foi vista por setores do establishment como uma ameaça iminente à ordem estabelecida.

Dessa forma, a ampliação do consenso democrático, pós-derrocada do regime ditatorial (1964-1985) e promulgação da Constituição de 1988, fez emergir uma série de movimentos por reconhecimento de direitos, que traduziram-se em conquistas cristalizadas no âmbito jurídico, com leis que garantem direitos e visam ampliar a igualdade: entre gênero, raça e diversidade de orientação sexual; na esfera social, a partir de leis que estabelecem cotas para minorias no acesso aos ensinos médio, técnico e universitário, além da reserva de vagas em concursos públicos na esfera federal; no âmbito da cultura, a partir da patrimonialização de uma série de bens culturais ligados às religiões de matriz africana, entre outros. Ironicamente, os grupos evangélicos pentecostais - pontas de lança da reação 
contra a tramitação e concretização de diversas das iniciativas elencadas acima foram beneficiários de primeira hora do processo de democratização do país, no que Burity (2016; 2018; 2020), baseado na proposta de Connolly (2011), chama de minoritização das crenças.

Nesse contexto, evangélicos pentecostais reivindicam sua maior presença no espaço público, falando do lugar de minorias religiosas (Machado e Burity, 2014), que sempre estiveram marginalizadas seja na política, seja na cultura mais ampla, principalmente, frente a uma Igreja Católica ou a uma cultura laica, vistas como hegemônicas na ocupação de cargos públicos ou visibilidade midiática.

É fato já bastante ressaltado na literatura nacional a proeminência das agências religiosas, em especial do catolicismo, como coprodutoras da sociedade civil brasileira (MAINWARING, 1985; GUIMBELLI, 2002; MONTERO, 2012), no entanto, quando assistimos a embates entre movimentos organizados da sociedade civil e líderes religiosos a respeito do lugar da religião na esfera pública, pensamos que algo possa ter mudado desde a época em que o catolicismo, em sua vertente popular, romanizada ou da libertação, ocupava o centro dessas discussões. Mas o que teria mudado com a entrada dos evangélicos (pentecostais, neopentecostais e renovados) e católicos carismáticos na cena pública? Qual o escopo dessa mudança, que tem levado pesquisadores a associarem tal cenário a imagens como crise (ALMEIDA, 2019) ou regimes autoritários como “cristofascismo" (PY, 2019), e atores sociais a afirmarem que estamos diante de uma ameaça real à democracia?

Para entendermos tal processo, precisamos considerar não só a já mencionada onda populista conservadora que se precipitou sobre diversas partes do mundo, dos EUA à Itália, passando pela Índia (MAZUMDAR, 2017), mas também a conjuntura política brasileira da última década, marcada por uma cruzada moral no combate à corrupção, ensejada e levada a cabo pela Operação Lava Jato e, principalmente, a forma como a elasticidade do discurso evangélico consegue traduzir estes cenários de instabilidade em sínteses discursivas capazes de oferecer mapas de ação para seus adeptos. 
Para bem da exposição, em um primeiro momento trataremos de aspectos mais gerais, como a mudança estrutural descrita por Habermas (2003; 2007), bem como os reparos e acréscimos levantados por Mouffe sobre as teorias deliberativas (MOUFFE, 2000 e 2005). Nesse tópico começaremos a fundamentar tanto o novo relevo do discurso conservador mais amplo como argumento legítimo nos assuntos públicos quanto o surgimento do discurso religioso como síntese discursiva desse processo.

Em um segundo momento, dedicado à conjuntura brasileira, argumentaremos que não é a presença religiosa, em especial a evangélica, que introduz o discurso conservador na arena pública, mas ao contrário, o aguçamento da legitimidade de argumentos conservadores constitui e impulsiona o próprio processo de publicização dos pentecostais desde a Constituição de 1988, além de fazer parte da própria história republicana brasileira (PIERUCCI, 1987; J. M. CARVALHO, 2008). Dito de outra forma, a nova vaga de legitimidade de argumentos conservadores que assistimos organizar o debate político na atualidade faz parte da correlação de forças desde o processo de abertura democrática e se tornou agudo com a chegada do Partido dos Trabalhadores ao poder em 2003, constituindo e auxiliando o próprio processo de publicização dos evangélicos, que se tornam peças centrais nesse tabuleiro ao sintetizarem discursivamente e impulsionarem o conservadorismo.

\section{Antagonismo e publicização religiosa}

Em seu trabalho Entre naturalismo e religião (2007, p. 119-120), Habermas propõe algumas teses que empreendem uma reconciliação entre pensamento racional e religioso, ao mesmo tempo que tenta fixar o sentido e o lugar do religioso dentro das democracias liberais. Na proposição de Habermas, um Estado liberal, ainda que possa obter sua autolegitimação de maneira autossuficiente, através de recursos cognitivos que não dependam de discursos estranhos à esfera política, necessita manter a aderência de seus "cidadãos do Estado", ou seu status, por meio 
de pequenas virtudes do político, ou seja, por meio de uma sociedade civil que se alimenta de fontes "pré-políticas".

Para o autor, ao contrário dos “cidadãos da sociedade” (Gesellschaftbürger) - que são destinatários do direito - os cidadãos do Estado (Staatsbürger) se autoentendem como coprodutores das leis e, nas palavras de Habermas, "devem assumir seus direitos de comunicação e de participação de modo ativo, não somente no sentido bem-entendido do interesse próprio, mas também devem ser orientados pelo bem comum" (HABERMAS, 2007, p. 119). Nesse modelo, os discursos religiosamente articulados - à moda da teologia medieval e da alta Escolástica espanhola, que estão na gênese dos direitos humanos (Idem, p. 116) serviriam como motivadores do engajamento público dos cidadãos do Estado, conteúdo normativo, desde que traduzidos para linguagem acessível em geral.

Se acompanharmos a linha argumentativa de Entre naturalismo e religião, poderíamos nos perguntar: se a ágora pública necessita de discursos pré-políticos para manter os seus cidadãos do Estado engajados, e se esses discursos devem, nas palavras de Habermas, ensejar valores universais e um bem comum, o que aconteceria se ao invés de um espaço público dialógico estivermos diante de uma arena pública escassa, ou nas palavras de Sennett (1999, p. 28), um espaço público morto, em que a exacerbação das relações impessoais de mercado leva a uma privatização da sociedade e ao autocentramento na instrumentalização do mundo, de modo que o sujeito não confere nenhuma legitimidade a demandas externas a seus self, como em Taylor (OLIVEIRA, 2006)?

Bem, esta é obviamente uma das possibilidades consideradas por um pensador arguto como Habermas, sendo uma das hipóteses levantadas em seu Entre naturalismo e Religião, mas descartada para sociedades liberais mais consolidadas. Habermas observa que, uma modernização "descarrilhadora" da sociedade poderia esgarçar, em sua totalidade, o laço democrático e consumir o tipo de solidariedade da qual o Estado democrático depende, o que levaria à transformação de cidadãos em mônadas individualizadas que agem guiadas pelos 
próprios interesses e que acionam seu direito subjetivo como se fossem armas apontadas para os outros. Em seu entendimento, "em sociedades onde impera uma economia mundial, e uma sociedade mundial, é possível detectar evidências de um esmigalhamento da solidariedade de cidadão do Estado" (HABERMAS, 2007, p. 121). Para o autor, em tese que, nesse caso, aproxima-se das de Taylor (1994; 2011) e Sennett (1999), os mercados, que não podem ser democratizados da mesma maneira que administrações estatais, assumem cada vez mais funções de controle e domínio da vida, que até então tinham sido mantidas de forma normativa por tipos de comunicação política ou pré-política. Tal processo inverte a polaridade das esferas privadas, transpondo o agir orientado pelo sucesso e por preferências próprias, fazendo encolher, por conseguinte, os domínios que dependem de pressões de legitimação pública, fortalecendo a privatização das agências de cidadãos do Estado (HABERMAS, 2007, p. 122).

Aterrizando no caso brasileiro, podemos pensar - provisoriamente - que o processo de redemocratização do país, levado a cabo após a Constituição de 1988, não chegou a realizar o projeto de constituir uma arena pública dialogal, como prescreve Habermas (2003), antes, assistimos ao fatiamento das instituições do Estado entre os conglomerados financeiros que, por sua natureza, são não democráticos. Dessa forma, o que testemunhamos desde o agudo processo de privatização dos governos Collor e $\mathrm{FHC}^{2}$, com refluxos em áreas específicas nos governos do Partido dos Trabalhadores, foi a inclusão de diversos setores da sociedade brasileira em uma espécie de "cidadania pelo consumo", periférica. Parte de setores importantes para o acesso a uma cidadania plena, como saúde, educação, segurança e transporte, foram entregues à inciativa privada e dependiam do interesse pecuniário destas para seu desenvolvimento pleno. Não foi sem motivo que as manifestações de junho de 2013 tiveram como estopim o aumento do custo do transporte público.

\footnotetext{
${ }^{2}$ Presidentes Fernando Collor de Mello, que presidiu o país entre 1990-1992 e Fernando Henrique Cardoso (FHC), que foi presidente por dois mandatos, entre 1994-2002.
} 
Nos governos petistas (2003-2016), ainda que se tenha avançado em políticas de inclusão social e cidadania, reconhecendo várias demandas de grupos minoritários, "viu-se a inclusão de vastos setores da sociedade no processo violento de valorização do capital, implicando uma integração que, contraditoriamente, não significava necessariamente cidadania” (SINGER, 2016, p. 13). Diante de tal cenário, assistimos a uma cultura política que é premida, de um lado, pelos interesses privados associados ao Estado - impondo uma espécie de "teto" ao acesso à cidadania - e desgastada de outro, por um discurso que parece imputar ao ocupante do Estado, no caso o PT, o papel de único artífice e responsável pelas contradições e limites do arranjo mercado-cidadania, potencializando e até precipitando o esgarçamento completo das instâncias democráticas. Nesse ínterim, presenciamos a emersão de diversos discursos de base moral, até então periféricos ao debate político desde a derrocada do udenismo no início da Ditadura Militar de 1964 (BENEVIDES, 1981).

É justamente neste ponto que lançamos mão das críticas de Chantal Mouffe no que a autora denomina modelo do "consenso democrático", representado principalmente por autores como Raws e Habermas (MOUFFE, 2005), mas, também, pelo projeto de "terceira via” de Giddens (MOUFFE, 2015). Nesse sentido, sem querer malbaratar uma discussão que é complexa, focaremos nossas lentes em duas proposições das teorias do "consenso democrático" e nas críticas interpostas por Mouffe. Em nosso entendimento, as propostas se articulam ao argumento que desenvolvemos no próximo tópico, alinhavando a crise brasileira da última década, a ascensão de Bolsonaro ao poder e o protagonismo dos evangélicos em termos de política.

Em primeiro lugar, segundo Mouffe, há por parte da teoria do "consenso" uma tentativa de conciliar a "liberdade dos antigos" à "liberdade dos modernos", ou seja, "na crença de que através de adequados procedimentos deliberativos seria possível superar o conflito entre os direitos individuais e as liberdades, por um lado, e as demandas de igualdade e de participação popular, por outro" (MOUFFE, 2003, p. 25); depois, há a ideia de que se pudesse estabelecer um consenso racional 
a respeito dos assuntos públicos (MENDONÇA, 2010). A esses dois postulados Mouffe argumenta, ainda nas primeiras páginas de Sobre o político (2015), que, ao contrário dos que veem o político como um lugar da liberdade e da discussão pública, ela toma o político como espaço do poder, de conflito e de antagonismo.

Como bem observa Daniel Mendonça (2010, p. 488), Mouffe aponta a tentativa de conciliação entre liberalismo e democracia como o principal "paradoxo da democracia moderna”, ancorada na sempre frustrada tentativa de conciliação entre esses dois polos. A autora acrescenta que a proposição de uma resolução racional das contendas públicas advindas da incomensurabilidade entre a "liberdade dos antigos" versus a do "modernos" passa por uma negação do político e principalmente dos antagonismos constitutivos deste. Nas palavras de Mendonça (2010), para a autora a solução racional pode fechar o espaço constitutivo da democracia, que separa justiça do direito, sendo, porém, a tentativa de subsumir os conflitos públicos em discurso racional inócua, uma vez que a realidade social e as demandas identitárias se mostram multifacetadas constitutivas e constituintes do próprio processo político.

Desta forma, para Mouffe (2015) a visão pós-política, ao negar o antagonismo constituinte do político, advogando uma superação da clivagem entre esquerda e direita, a superação das identidades coletivas e a chegada de um novo tipo de eleitor - o individualista, sem ligação com partidos tradicionais - agora vê, como raio em céu aberto, a ascensão ao poder de lideranças populistas, que apelam para noções "arcaicas", como identidades coletivas, povo e nação. Nesse bojo, para a autora, o renascimento de um populismo de direita não está ligado a uma memória de um passado autoritário de certas nações, como a Áustria, por exemplo, ou ao pouco letramento e a ignorância de certos setores da população, mas antes, ao fechamento do político para o exercício da disputa pelas demandas antagônicas. Em termos mais concretos, segundo a autora, a chegada ao poder de partidos e lideranças populistas de direita se deve ao esmaecimento das diferenças de pautas entre partidos democráticos tradicionais, ou pelo deslocamento ao centro de partidos que se colocavam nitidamente à esquerda, como na França. 
Debruçando-se sobre o caso austríaco, Mouffe nos mostra como um líder populista, Jörg Haider, do Partido da Liberdade Austríaco (FPÖ), beneficiando-se de um cenário de pouco contraste político advindo da aliança entre o conservador Partido do Povo (ÖVP) e o Partido Socialista (SPÖ), estabelecido logo depois da Segunda Guerra, conseguiu mobilizar uma ampla base popular contra uma elite política que ocupava os principais postos do país.

À semelhança de nossa tragédia tupiniquim, na Áustria, Haider conseguiu estabelecer uma dicotomia entre um “'nós' formado por todos os austríacos de bem, trabalhadores dedicados e defensores dos valores nacionais, e um 'eles' composto pelos partidos no poder, sindicatos, burocratas, estrangeiros, intelectuais de esquerda e artistas, que eram apresentados como um obstáculo ao verdadeiro debate democrático” (MOUFFE, 2015, p. 66), tendo como resultado um salto em sua participação no votos do país, que chegou a 27\% em 1999.

Mouffe continua páginas a fio a amontoar exemplos da ascensão do populismo de direita em países da Europa, do caso clássico austríaco ao francês, passando pela Bélgica, todos repetindo a fórmula de recuperação das identidades coletivas de um nós versus um eles, povo versus “anti-establishment”. Em resumo, em um contexto em que os governos locais parecem ter perdido seu poder de decisão frente aos feixes híbridos de informações globais, que misturam ideias a fluxos de capitais, colocando em xeque modos tradicionais de organização social, não é surpresa que um número cada vez maior de pessoas deposite suas esperanças em lideranças que prometem resistir a esses fluxos, restaurando a aura perdida da sociedade.

Pois bem, mesmo que de forma matizada, parece-nos que é sobre a mesma engrenagem que Jair Bolsonaro é eleito presidente e assistimos a esta nova lufada do conservadorismo religioso, agora em sua face evangélica, organizando discursivamente parte das pautas públicas no país - lembramos que o discurso católico de fundo conservador foi uma importante força na organização do 
pensamento de direita no Brasil, bem como uma das linhas de força do Golpe Militar de 1964 (CODATO e OLIVEIRA, 2004).

Porém, neste artigo, interessa-nos o papel que os grupos evangélicos desempenham na articulação de um discurso conservador em torno de um ponto nodal (LACLAU e MOUFFE, 2014) comum e articulador, o antipetismo, que se constitui no elo capaz de estabelecer uma cadeia de equivalências entre as diversas demandas de ordem moral, econômica e social espraiadas de forma difusa na sociedade. Portanto, ao se mobilizar em torno de demandas como segurança, família e educação, por exemplo, os grupos evangélicos produzem um discurso conservador com "articulações concretas que unem palavras e ações, no sentido de produzir sentidos que vão disputar espaço no social” (MENDONÇA, 2009, p. 157).

\section{A derrocada petista e o protagonismo evangélico: urdidura de antagonismos}

Em um primeiro momento, concentraremos nossas atenções na via políticoeleitoral pentecostal e na sua constituição como verdadeiros partidos religiosos (BURITY, 2018 e 2020), para, em seguida, pontuarmos o processo que permitiu aos evangélicos se deslocarem do papel de minorias religiosas - e base lulista para peças fundamentais no afloramento de antagonismo que contribuíram para a contestação do governo petista. Como bem aponta Burity, se em um primeiro momento os evangélicos disputavam espaço sem negar o direito à existência dos adversários, paulatinamente passam a operar em uma "lógica populista de dicotomização do espaço público", instrumentalizada pela oposição, principalmente após a eleição de 2014 (BURITY, 2018, p. 40).

Pegando o fio desta meada, nesse percurso matizado até o rompimento, várias lideranças, que hoje vocalizam o discurso conservador, apoiaram o governo Lula e Dilma em algum momento, entre estas destacamos o Pastor Silas Malafaia (ADVEC), Bispo Robson Rodovalho (Sara Nossa Terra) - que, em 2002, lançou um manifesto pró-Lula e apoiou Dilma Rousseff em 2010 -, sem falar do Bispo 
Macedo (IURD) que, em 2010, divulgou carta de apoio3 a Dilma, após ataques sofridos pela candidata na internet. Lembramos, ainda, que a IURD teve quadros integrando alguns ministérios dos governos petistas até as vésperas da abertura do processo de impeachment contra Dilma Rousseff em 11 de abril de 2016, ocasião em que o ex-ministro dos Esportes e deputado Pastor George Hilton votou contra a admissibilidade do processo.

Então resta a pergunta: como se dá a ruptura entre evangélicos e os governos petistas? Para responder essa questão acreditamos ser necessário o entendimento de dois processos: primeiro, o que aproxima os evangélicos do petismo, pois é o mesmo pêndulo que os leva de volta para longe; depois podemos seguir para o entendimento de que forma uma miríade de denominações religiosas do "espectro evangélico" passa a articular suas demandas a partir de cadeias de equivalência (LACLAU e MOUFFE, 2014), que têm como ponto central a ideia de que o país ruma para um lugar trágico devido à carência moral, em uma palavra, a corrupção, que em dado momento se unifica em torno de uma particularidade partilhada em oposição a algo excludente: o PT. Dito de outra forma, além de entendermos as razões da aproximação e distanciamento entre evangélicos e PT, buscaremos deixar clara, em um segundo momento, a constituição da identidade evangélica que articula uma série de demandas em termos de discurso religioso conservador, criando uma gramática de ação política (NATALUCCI, 2015) que transborda as fronteiras das denominações religiosas.

Nesse bojo, mesmo sendo o PT que chegou ao poder em 2003, um partido bem diferente do forjado nas décadas de 1970 e 80, como bem apontam Miguel e Biroli (2017), seu governo trouxe para o acesso ao Estado, grupos que fizeram parte de sua base social desde a sua fundação. Tal ampliação do consenso democrático incluiu, mesmo que de forma periférica, movimentos que reivindicavam direito à terra, sindicalistas, integrantes de movimentos negros, feministas, gays, além dos evangélicos, claro.

\footnotetext{
3 Disponível em: https://www1.folha.uol.com.br/poder/2010/09/806780-edir-macedo-divulga-carta-em-apoio-a-candidatura-dedilma.shtml. Acesso em: 28 set. 2019.
} 
Parece redundante frisar a dificuldade do governo na acomodação dos diversos grupos e interesses privados dentro da mesma coalisão que, além de serem pratos demais para as mãos do equilibrista, fomentavam a participação pública de setores da sociedade até então alijados do jogo democrático, desorganizando as peças do tabuleiro. Por seu turno, a incorporação de demandas sociais à agenda dos governos não significa a diluição automática dessas demandas, ao contrário, muitas vezes, o que assistimos é ao incremento ou deslocamento destas. Por exemplo, a Lei "Maria da Penha", as políticas afirmativas com relação a cotas raciais, ou o reconhecimento do nome social para pessoal LGBTQIA+, não esgotaram suas demandas por direitos, mas engendraram novas demandas, que desafiaram e desorganizaram as hierarquias sociais, ameaçando não só o privilégio das elites mas, principalmente, as distinções que alicerçavam as relações sociais como o patriarcalismo e o racismo.

Lembremo-nos da famosa frase do então pré-candidato Jair Bolsonaro durante o programa Roda Viva, da TV Cultura, em que perguntado sobre a política de cotas e a dívida histórica com a população afrodescendente, responde: "Que dívida? Eu nunca escravizei ninguém na minha vida"4. Tal frase soa como música para os ouvidos de parcela da população, que não quer abrir mão de seus privilégios - vistos como direitos - em prol de uma ordem social injusta, cujas raízes históricas não foram por eles plantadas. Ou seja, voltamos ao problema habermaziano que enunciamos ainda no início deste tópico, ou seja, um indivíduo atomizado não vê nenhum motivo para se sacrificar em prol da coletividade. Voltaremos a esse ponto de forma mais sistemática à frente.

O período lulista (2003-2016), ainda que tenha fomentado uma cadeia de equivalências (Laclau e Mouffe, 2014) que permitiu a articulação de demandas de diversos setores marginalizados da sociedade, acabou precipitando um novo posicionamento de classes dentro do sistema, processo similar ao que aponta Adam Przeworski (1989) para a social democracia europeia. Assim, ao pretender alargar

\footnotetext{
${ }^{4}$ Disponível em: https://noticias.uol.com.br/politica/eleicoes/2018/noticias/2018/07/31/bolsonaro-diz-que-pretende-reduzir-cortasnunca-escravizei-ninguem.htm. Acesso em: 25 out. 2019.
} 
sua base eleitoral, o PT diluiu os interesses específicos dos trabalhadores enquanto classe, ao mesmo tempo em que ampliava - incluindo nos circuitos de crédito e consumo - e transformava sua base eleitoral, tanto do ponto de vista objetivo, material, quanto do ponto de vista subjetivo, no sentido de Dardot e Laval (2016).

Neste ponto, a leitura da obra de André Singer, Os sentidos do Lulismo (2012), leva-nos à conclusão de que o grande feito do lulismo foi inaugurar um jogo de ganha-ganha, - tese com a qual Singer não concordaria, preferindo a ideia de um reformismo fraco (SINGER, 2012) -, ou seja, combater a pobreza sem, no entanto, superar a desigualdade5. O livro de A. Singer (2012) nos chama a atenção para um aspecto importante para nosso argumento, ou seja, o deslocamento da base de apoio do PT, que, a partir de 2006, migrou das classes médias escolarizadas urbanas para o que Paul Singer (1981) classificou como “subproletariado". Nas palavras de P. Singer, o subproletariado é composto por "aqueles que oferecem a sua força de trabalho no mercado sem encontrar quem esteja disposto a adquiri-la por um preço que assegure sua reprodução em condições normais" (1981, p. 22), o que inclui “empregados domésticos, assalariados de pequenos produtores diretos e trabalhadores destituídos das condições mínimas de participação na luta de classes” (1981, p. 83). Do ponto de vista político, o subproletariado tem feições conservadoras, desejava um Estado ativo na redução da pobreza, mas sem colocar em questão a ordem social (MIGUEL, 2013).

Aqui começamos a conectar as duas pontas de nosso argumento, ou seja, subproletariado e evangélicos. Como é sabido, ainda que tenha se transformado significativamente nas últimas décadas do ponto de vista socioeconômico, o grupo evangélico ainda é composto em sua maioria por pessoas com menos anos de instrução, que se declaram como negros e pardos, residentes na periferia das grandes cidades, que ocupam o setor de serviços (BOHN, 2004; ARAÚJO, 2019) e que tradicionalmente compõem a base eleitoral da direita (PIERUCCI, 1989;

\footnotetext{
${ }^{5}$ Autores como Sallum Jr. e Kugelmas (2004) afirmam que se estabeleceu um consenso liberal desenvolvimentista que atuou fortemente no sentido de despolarizar o debate público.
} 
MARIANO e PIERUCCI, 1992). Porém, teriam migrado para a base lulista paulatinamente, primeiro ao terem seus líderes admitidos no governo petista, depois por se verem incorporados no que chamamos, páginas atrás, de "cidadania pelo consumo".

Nesse sentido, é interessante retomar dois momentos: o primeiro, ocorrido em outubro de 2002 quando, após o primeiro turno das eleições daquele ano, um grupo de pastores se reúne em uma churrascaria da Zona Norte do Rio de Janeiro, capitaneados pelos pastores Everaldo e Silas Malafaia, para declarar apoio ao então candidato Lula; e outro, ocorrido em 2013, quando Marcelo Crivella, então ministro da Pesca do governo Dilma, discursa durante a Convenção das Assembleias de Deus. Observando o enfoque dos dois discursos, separados por mais de uma década, vemos o deslocamento das demandas e o ancoramento das expectativas.

No primeiro caso, Lula diz que quer contar com as igrejas evangélicas para atacar os problemas sociais do país: "Vocês nunca, na história da igreja evangélica, foram chamados à responsabilidade e a participar da construção desse país como eu vou chamar (...)”, em seguida, destaca como igrejas e ONGS têm sido mais eficientes que o próprio Estado no combate às desigualdades. No mesmo evento, o pastor Everaldo ressalta que os "evangélicos querem o compromisso do governo Lula com a queda dos juros, políticas de renda, emprego e educação e com a liberdade para atuação das várias igrejas evangélicas"6, além da valorização do salário mínimo. É importante frisar que tais demandas são pautas diametralmente opostas a que o próprio pastor defendeu em 2014, quando foi candidato à Presidência, apresentando uma agenda bastante liberal.

Já no evento de 2013, Crivella diz que se deve aplaudir Dilma, já que as políticas públicas dela eram voltadas para a população pobre:

\footnotetext{
${ }^{6}$ Disponível em: https://noticias.uol.com.br/inter/reuters/2002/10/17/ult27u27501.jhtm. Acesso em: 10 nov. 2018.
} 
A nossa presidenta e o presidente Lula fizeram a gente crescer porque apoiaram os pobres. E o que nos sustenta são dízimos e ofertas de pessoas simples e humildes (...). Com a presidenta Dilma, os juros baixaram. Quem paga juros é pobre. Com menos juros, mais dízimo. (...) Quando sobra dinheiro, o povo evangélico não vai para a butique pra comprar roupa. Sabe o que o povo faz? Ele vai mais na igreja, dá mais oferta, mais dízimo, faz mais caridade. Então nós temos que aplaudir a presidenta Dilma7.

Os exemplos acima, mais que evidenciar dois momentos distintos da articulação entre evangélicos e política no Brasil, apontam para o deslocamento das demandas que emanam a partir da identidade de grupo e de suas aspirações no início dos anos 2000. Uma década depois, tanto as aspirações da base pentecostal/neopentecostal mudam, como mudam as de suas lideranças. Ainda que o discurso tenha sido proferido por Marcelo Crivella, bispo licenciado da IURD, o pronunciamento foi realizado em uma convenção nacional da Assembleia de Deus e dirigido aos seus pastores, que àquela altura não eram afeitos aos discursos de Teologia da Prosperidade. Por outro lado, aqueles pastores eram "gerentes" de suas próprias igrejas e sabiam das dificuldades de se manter uma "empresa religiosa" em meio à concorrência voraz de um mercado cada vez mais competitivo.

Nesse sentido, as empresas religiosas foram ganhando autonomia inclusive de seus aspectos doutrinais, sendo um bom exemplo a querela instaurada com a interdição dos cultos presenciais por conta da pandemia de Covid-19, em que lideranças religiosas acionaram a justiça para manter as igrejas abertas. Nesse ponto, ainda que a ameaça da Covid-19 tenha sido, muitas vezes, traduzida em metáforas religiosas, como por exemplo, "tática de Satanás", segundo Macedo ${ }^{8}$, a maioria dos pastores não esconde que a principal preocupação com o fechamento das igrejas era a queda na arrecadação dos dízimos 9 . Voltaremos a esse ponto mais adiante, quando discutiremos a formação de subjetividades neoliberais e a lógica das igrejas evangélicas.

\footnotetext{
7 Disponível em: https://politica.estadao.com.br/noticias/geral,lula-e-dilma-ajudam-os-pobres-que-dao-mais-dizimo-diz-ministro-dapesca,1012125. Acesso em:

${ }_{8}^{8}$ Disponível em: https://jc.ne10.uol.com.br/brasil/2020/03/5603046-apos-desafio-de-malafaia-e-macedo--mp-sp-cobra-doria-e-covassuspensao-de-cultos-por-causa-do-coronavirus.html. Acesso em: 25 jul. 2020.

${ }_{9}^{9}$ Disponível em: https://www.radiogazetaorlandia.com.br/coronavirus-afeta-igrejas-paguei-conta-do-bolso-diz-pastor/. Acesso em: 25 jul. 2020.
} 
Voltando ao trabalho de A. Singer (2012), observamos uma tabela baseada em dados de pesquisas de opinião feitas em 2002, 2006 e 2010, que trazem a posição dos apoiadores do PT, segundo espectro político com o qual se identificam (SINGER, 2012, p. 119). Nessa pesquisa ficamos sabendo que nada mais nada menos que 35\% dos que apoiavam o PT em 2010 se identificavam como de direita, menos, por exemplo, que os que se identificavam com a esquerda, 32\%. Tal evidência se torna ainda mais significativa quando sabemos que, em pesquisa realizada em São Paulo em maio de 2018, durante o evento evangélico Marcha para Jesus, Lula - naquela altura ainda candidato do PT, mas já preso em Curitiba -, mantinha-se como líder das preferências com 20,09\%, enquanto que Bolsonaro aparecia com 15,69\%, em segundo lugar ${ }^{10}$; em pesquisa do Instituto Ideia Big Data, divulgada no dia 27 de julho de 2018, portanto, quase quatro meses após estar preso, Lula ainda empatava tecnicamente com Bolsonaro entre os pentecostais, 24\% para aquele e 25\% para esse; entre os batistas Bolsonaro bate $28 \%$, diante de $22 \%$ de Lula; enquanto que entre os neopentecostais fica com $26 \%$ ante os $31 \%$ de Bolsonaro ${ }^{11}$.

No entanto, em pesquisa do Datafolha divulgada no dia 25 de outubro de 2018, portanto três dias antes das eleições, Bolsonaro superava Haddad entre os evangélicos em mais de 30 pontos percentuais, ficando em 69 contra 31\% dos votos válidos. Projetando-se para o resultado das urnas, segundo Alves (2018), a diferença entre os dois candidatos foi de 11,6 milhões de votos entre os evangélicos, portanto, maior que a diferença total de votos (10,7 milhões) registrada entre os dois candidatos no resultado final. Essa constatação levou a uma série de afirmações e análises que davam conta do peso dos evangélicos no pleito: muitos afirmavam que atuaram como fiéis da balança (ALVES, 2018), o que obviamente ouriçava as lideranças evangélicas que assistiam ao seu capital político valorizar vertiginosamente com a eleição de Jair Bolsonaro.

\footnotetext{
${ }^{10}$ Pesquisa realizada durante a Macha para Jesus de São Paulo, em 31 de maio de 2018, coordenada por Leandro Ortunes, "Entre Deus e o voto evangélico e as eleições de 2018". São Paulo: Núcleo de Estudos em Arte, Mídia e Política (NEAMP) da PUC-SP em parceria com o MIRE-GP Comunicação e Religião da INTERCOM.

${ }_{11}$ Disponível em: https://veja.abril.com.br/politica/bolsonaro-lidera-entre-eleitor-evangelico-com-ou-sem-lula-candidato/.: Acesso em: 28 set. 2018.
} 
Por outro lado, alguns pesquisadores chamaram a atenção para a complexidade do contexto e o caráter matizado do peso que a confissão religiosa teria tido no pleito de 2018. Alexandre Brasil Fonseca (2018), por exemplo, relativiza a tese do peso evangélico na eleição de Bolsonaro, apontando para sua expressiva vitória em Santa Catarina, estado em que o candidato teve sua segunda maior votação proporcional $(75,92 \%)$, sendo, no entanto, a população evangélica do estado de $20 \%$, inferior inclusive que a média brasileira.

De qualquer forma, é importante observar que, quando olhamos dados sobre votação por zonas eleitorais, observamos que há uma inequívoca afinidade eletiva, nos termos de Goethe, entre as regiões com maior percentual de evangélicos e o voto em Bolsonaro. Para ficarmos apenas no caso do Rio de Janeiro, as zonas eleitorais dos bairros de Santa Cruz, Bangu, Paciência, bairros da Zona Oeste ${ }^{12}$, em que a predominância evangélica já ultrapassava os 30\% no censo de 2010 (GRACINO JUNIOR, 2016), apresentavam cifras muito elevadas para Bolsonaro, todas com mais de $60 \%$ já no $1^{\circ}$ turno. Somado a isso, são a regiões em que o Cabo Daciolo, o candidato que mais articulou seu discurso em imagens religiosas do mundo evangélico, auferiu seus melhores resultados, ultrapassando a casa dos $3 \%$ em algumas delas. Por outro lado, a Zona Oeste concentra os territórios em que o PT teve seus piores percentuais, em muitas zonas eleitorais, não chegando aos 10\%. No segundo turno vimos algo similar, a Zona Oeste foi a região em que Bolsonaro teve seus melhores percentuais na cidade do Rio de Janeiro, atingindo mais de 70\%, com destaque para o bairro de Campo Grande, em que bateu mais de 75\% dos $\operatorname{votos}^{13}$.

Certamente, os evangélicos não são os únicos demiurgos da eleição de Bolsonaro, muito menos são os ideólogos de primeira hora do bolsonarismo, mas, seguramente, colocam-se na ponta de lança do projeto de hegemonia do pensamento conservador em curso no país (BURITY, 2020). No entanto, como argumentamos até aqui, foi necessário um processo lento de transformação das

\footnotetext{
${ }^{12}$ Obviamente a Zona Oeste do Rio de Janeiro, além de ser uma região que concentra muitos evangélicos, é um território dominado pelas Milícias, que possuem afinidades múltiplas com o candidato Bolsonaro.

${ }^{13}$ Disponível em: http://divulgacandcontas.tse.jus.br/divulga/. Acesso em: 2 fev. 2019.
} 
massas urbanas via integração marginal na sociedade de consumo, uma espécie de “via prussiana popular" cozida lentamente em um caldeirão que tinha como principal ingrediente uma política econômica que tentava articular os interesses da elite econômica às necessidades da parcela mais precarizada da população, no que a pesquisadora argentina Verónica Gago chamou de “economias barrocas” (GAGO, 2018).

Nesse sentido, tanto o trabalho de Cibele Rizek (2016) quanto o de Gago (2018) são pródigos em apontar o caráter nuançado desta penetração do capitalismo nas periferias das grandes cidades, como São Paulo e Buenos Aires, transformando os sujeitos, suas formas de subjetivação e a pragmática de si na intrincada mescla com o que Gago chama de "neoliberalismo de baixo para cima”, ou seja, "um conjunto de condições que se concretizam para além da vontade de um governo (...) mas que se transformam diante das condições sobre as quais opera uma rede de práticas e saberes que assume o cálculo como matriz subjetiva primordial (...)” (GAGO, 2016, p. 19), funcionando como um motor da economia popular, “um saber-fazer na crise”, que desemboca em uma autoempresarialidade, como observa a autora.

Para Gago o encontro entre estímulos neoliberais e economia popular gera o que a autora chama de pragmática vitalista, estabelecendo o cálculo como condição vital para a obtenção da sobrevivência em territórios em que o governo não garante as condições neoliberais de competição (GAGO, 2016, p. 20). Em nosso entendimento, é aqui que entram as igrejas evangélicas, muitas delas funcionam, como dissemos acima, como molas mestras, tanto na produção de subjetividades doutas dessa racionalidade pragmática quanto de dinâmicas cooperativas que resistem a essas lógicas de exploração.

O crescimento do pentecostalismo e a replicação de inúmeras igrejas pelos bairros e periferias do país acabam funcionando como empreendimentos de fé que concorrem entre si pela atenção e adesão do fiel. Tal cenário levou os pastores a tomarem contato com técnicas e discursos administrativos (CAMPOS, 1997; 
SOUZA e PINTO, 2013; CORTES, 2014), para além da teologia da prosperidade iurdana, que, por sua vez, foram traduzidos para linguagem teológica e espraiados, assimilados, ressemantizados e postos em marcha pelos fiéis (GRACINO JUNIOR, 2008).

Nesse bojo, as igrejas passam a ser grandes cabeças de ponte desse processo, à medida em que ganham corpo, uma visão concorrencial do mundo social ou, nas palavras de Dardot e Laval (2016), são fabricados os sujeitos neoliberais, derivados de um "sistema normativo que ampliou sua influência ao mundo inteiro, estendendo a lógica do capital a todas as relações sociais e a todas as esferas da vida" (DARDOT e LAVAL, 2016, p. 7). Ao mesmo tempo em que oferecem um mapa discursivo que engendra as novas subjetividades flexíveis, entrelaçando saberes locais práticos (pragmática vitalista) e processos gerenciais atuais, oferecem refúgio e estratégia de resistência contra processos de individualização. Propõem restaurar a autoridade paternal frente às ameaças de desintegração da família, criam uma rede de confiança - uma clientela - em um mercado cada vez mais anônimo.

Assim, voltamos a Gago (2016) e aos conceitos de governamentalidade e política dos governados tomados de empréstimo de Chartterjee (2004), que, segundo a autora, tensionam o conceito foucaultiano ao colocá-lo em contato com a ideia de política popular. Nessa perspectiva, os governados não são vistos como povo, sujeitos da soberania do Estado, mas aqueles que sabem negociar, rechaçar os mecanismos de governamentalidade de que são objeto. Assim, a democracia depende da agência política daqueles que são alvo dos conhecimentos e técnicas de governo.

É interessante observar que a literatura sobre os pentecostais das décadas de 1980 e 1990 (NOVAIS, 1985; MARIZ, 1994; MARIZ e MACHADO, 1994; BURDICK, 1998) - em dissonância com os estudos do período anterior que viam a adesão ao pentecostalismo “como o refúgio das massas” (D’EPINAY, 1970) - já ressaltava a adesão ao pentecostalismo como estratégias de enfrentamento da 
pobreza, do alcoolismo e da violência doméstica. Enfim, para essas pesquisadoras e pesquisadores, o pentecostalismo oferecia mais que respostas às aflições (FRY e HOWE, 1975), impostas pela precariedade da vida nas periferias das grandes cidades. Mais que isso, fornecia narrativas que se transformavam em aprendizado, recursos discursivos para lidar com o sofrimento, a exclusão e a miséria. Auxiliavam no abrandamento dos afetos agressivos para os homens, ou em estratégias psicológicas com as quais as mulheres podiam lidar com a violência doméstica, passando para o suporte material e a introdução de uma nova lógica financeira e planejamento familiar.

De forma similar, mesmo que atravessado por outros processos, a adesão às igrejas evangélicas, além de forjar novas subjetividades afeitas ao neoliberalismo periférico, organiza uma gramática social através da qual os seus fiéis possam narrar suas demandas por segurança, estabilidade financeira e afetiva. Não é sem razão que as igrejas evangélicas, além de se constituírem como empreendimentos financeiros e possibilidade de carreiras de sucesso para alguns, deslocam seu discurso para passagens do Antigo Testamento, exaltando a lógica da guerra e do povo eleito, principalmente, nas periferias urbanas e violentas das grandes cidades.

No mesmo turno, o discurso teológico que enfatiza a família tradicional, o patriarcalismo, além de uma estratégia de busca angustiada de autoridade, frente a autonomia dos filhos, vista como ameaça nas periferias violentas das grandes cidades, espelham a clivagem na família tradicional, imposta pelos novos arranjos e empoderamento dos grupos feministas e LGBTQ+ (PINHEIRO-MACHADO e SCALCO, 2018). Assim, a contestação dos modelos de família, ainda que incidam sobre a masculinidade, tem nos seus principais antagonistas as mulheres, que são, na maioria das vezes, responsáveis pela reprodução do modelo de família tradicional e idealizada (MACHADO, 2020) ${ }^{14}$.

\footnotetext{
14 Mesa-Redonda. Religião e política: evangélicos hoje e o Brasil de amanhã. Rio de Janeiro: ISER. Disponível em: https://www.youtube.com/watch?v=H4A-jhxNHHA. Acesso em: 22 jul. 2020.
} 
Assim, quando as insatisfações com o governo petista começam a se pronunciar no céu limpo da política em junho de 2013, às vésperas dos grandes eventos (a popularidade de Dilma Rousseff era de 65\% em marco de 2013), lideranças como o Pastor Silas Malafaia já traziam como figuras centrais da Marcha para Jesus o então deputado federal Jair Bolsonaro. Desse ponto em diante, os evangélicos passam a atuar ativamente na urdidura de um campo discursivo antipetista, contando com o apoio cada vez mais contundente dos grupos midiáticos e de parte do Judiciário e da Polícia Federal, através da Operação Lava Jato.

\section{Mobilização discursiva e a opção conservadora}

Neste ponto da argumentação, ainda resta aprofundarmos a proposição sobre a maior capacidade de mobilização política do discurso religioso evangélico do tipo conservador, principalmente quando sabemos que, na história recente do Brasil, a Igreja Católica cumpriu um importante papel na aglutinação de interesses políticos e em sua tradução em discurso teológico através de Teologia da Libertação. Assim, seria um passo lógico aprofundarmos o argumento sobre o caráter individualista dos evangélicos, mais adaptado à estrutura do capital, versus o caráter comunitário humanista católico, especialmente frente ao legado do catolicismo da libertação para formação de movimentos sociais e luta pelos direitos humanos em nosso país. Principalmente se retomarmos alguns escritos bem recentes em que defendemos (GRACINO JUNIOR, 2016) que as instituições religiosas que têm logrado maior êxito em termos numéricos são as que se concentram nas preocupações com os medos sociais diários; nas crises financeiras; na violência vivida e/ou transmitida cotidianamente pelos meios de comunicação, ou nas diversas fantasmagorias que parecem ameaçar o núcleo familiar.

No entanto, Hans Joas (2012) argumenta de forma convincente sobre a gênese multifacetada dos direitos humanos, afastando as imagens religiosas do mundo como sendo componentes pretéritos per si dos direitos humanos, optando por um argumento mais construtivista e relacional sem, contudo, afastar o papel 
importante das ideias religiosas. Nesse sentido, Joas oferece um sem-número de evidências históricas em que a religião atuou tanto como demiurga da solidariedade quanto como catalizadora de guerras e perseguições sanguinárias. No mesmo turno, Francisco Rolim (1993), em um estudo sobre o pentecostalismo na América Latina, relata-nos casos em que grupos evangélicos, inclusive de cariz pentecostal, serraram fileiras com movimentos de esquerda, como no da Igreja Wesleyana Pentecostal no Chile, de forte penetração no meio operário, e o Movimento de Pastores Revolucionários, grupo de pastores ligados à Assembleia de Deus da Nicarágua.

Em trabalhos recentes (GRACINO JUNIOR, TARGINO e REZENDE, 2018 e 2019) temos chamado a atenção para a pertinência da proposta do sociólogo canadense Peter Beyer (1990) no que diz respeito à possibilidade de retomada da influência pública da religião na sociedade atual. Resumidamente, Beyer, ao analisar a possibilidade de renovação da influência pública das instituições religiosas nos dias atuais, propõe que a religião devesse dispor do controle sob um serviço nitidamente indispensável para a sociedade atual. Dessa forma, em uma sociedade que cada vez mais valoriza o pluralismo, os líderes religiosos poderiam fazer uso de modalidades religiosas tradicionais "para promover uma mobilização subsocial em resposta à globalização da sociedade” (BEYER, 1990, p. 396).

Dessa forma, a religião poderia alcançar e exercer sua influência pública através de duas formas de mobilização discursiva, a que o autor denomina como liberal e conservadora (Idem, ibidem, p. 407). Na primeira delas, há a consideração de que existe o mal no mundo, mas ele não pode ser localizado e/ou personificado de forma clara. O mal, nessa perspectiva, constitui uma limitação em todos nós e está presente em todas as estruturas sociais. Assim, o mal não pode ser localizado na pluralidade, incluindo aqui o pluralismo religioso. De fato, sob esse prisma, a intolerância e a imputação particularista é que se tornam a fonte do mal. Os profissionais da religião inclinados à opção liberal assumem uma postura ecumênica e tolerante, além de apontarem possibilidades de iluminação e de salvação em sua própria religião e em outras religiões. Para Beyer, o problema 
teológico fundamental dessa alternativa é que ela apresenta poucas exigências tipicamente religiosas, sendo que a maioria de seus atrativos também pode ser conseguida através de instituições não religiosas (1990, p. 408). Deus, por exemplo, é representado por essa vertente como sendo um ser benevolente e não vingativo, cuja única exigência é que as pessoas imitem suas atitudes em relação a seus semelhantes. No entanto, esta combinação de pluralismo e inclusão deixa de fora uma parcela ínfima dos indivíduos dos benefícios quase que automáticos da função religiosa (BEYER, 1990, p. 409).

Por outro lado, a opção conservadora vê o mal como algo tangível, promovendo a confirmação da visão tradicional da transcendência, confirmação esta que, muitas vezes, se concretiza como uma resposta normativa a uma sociedade que pode estar caminhando para uma direção desastrosa (ver também C. SMITH, 1998; 2003). Desta forma, diante da percepção de crise generalizada, as opções liberais oferecidas por religiões mais ecumênicas e inclusivas perdem terreno em meio às alternativas religiosas mais dicotômicas ${ }^{15}$.

Como já demonstramos alhures (GRACINO JUNIOR, TARGINO e REZENDE, 2019), o pastor Silas (líder da Assembleia de Deus Vitória em Cristo, promotora da Marcha para Jesus da cidade do Rio de Janeiro), talvez seja a liderança religiosa mais pródiga em oferecer exemplos para o que estamos tratando neste artigo. Após a eleição de Marcelo Crivella para a prefeitura do Rio de Janeiro em 2016, o pastor usou o Twitter para comemorar e escreveu: "Cambada de esquerdopatas se ferraram, tomaram uma lavada histórica. Calados! (...)”; “Crivella venceu a intolerância, preconceito, manipulação jornalística, e o melhor, a esquerda comunista (...)”; “Chora Capeta! Chora Freixo!”. Nesse sentido, mais que comentários hostis, as falas do pastor visavam mobilizar discursivamente tanto evangélicos quanto a parcela de seus seguidores não evangélicos, ao apelar para a macro identidade cristã: "Parabéns Cristãos! Nunca mais esses esquerdopatas vão nos enganar (...)”, ao mesmo tempo em que identifica um adversário tangível

\footnotetext{
${ }^{15}$ Foi justamente o que notou a cientista política Amy Erica Smith (2018) que, em pesquisa recente, destaca que a "ideologia de gênero" e a rejeição ao PT são os temas que mais mobilizam os eleitores "evangélicos" brasileiros.
} 
contra o qual lutar: "Ajudei a derrubar todos os candidatos do PSOL, PERDERAM TODOS! Pede o at gay [ativismo gay] para ajudar mais um pouco (...)" (GRACINO JUNIOR, TARGINO e REZENDE, 2019).

Dessa forma, o Twitter de Malafaia apela para um antagonismo absoluto, operando uma simplificação de uma realidade complexa, criando uma macroidentidade "nós” cristã-moral e, no mesmo turno, um "eles”, vistos como demiurgos da desestabilização social, depositários das mazelas e medos que afligem boa parte da sociedade em momentos de convulsão social, nesse caso, o “ativismo gay", o PSOL, os "petralhas", as "feminazis", ou simplesmente o mal, o "Capeta". Ainda é interessante observar como o discurso do pastor Silas Malafaia tem um duplo papel funcional, que ao mesmo tempo em que coloca o pastor em um lugar privilegiado na disputa pela arena religiosa brasileira, amplifica seu discurso para além da população evangélica.

Ao contrário de outros líderes do segmento evangélico pentecostal, que se concentram em soluções biográficas, como Edir Macedo, que dá ênfase a questões pecuniárias, ou a Waldemiro, que se concentra na cura, Silas surge com um produto bastante requisitado nos dias atuais, principalmente em tempos de Lava Jato, patos da FIESP e passeatas verde-amarelas contra a corrupção: a moral! O discurso moral proferido por Malafaia e replicado por um sem-número de outras lideranças evangélicas, como os também pastores e, nesse caso, parlamentares, como o senador Magno Malta (PR-ES) e o deputado Marcos Feliciano (PODE-SP), apresenta-se como um forte amálgama capaz de conectar ansiedades e medos pessoais, tributários de um momento histórico marcado por fortes transformações, ao discurso moral de fundo religioso e a uma narrativa de longa duração. Porém, o mal não está longe, não vem de fora, nem do estrangeiro, ao contrário, senta-se ao seu lado na escola, almoça com você no refeitório do trabalho, enfim, nos termos de Luhmann (2007), tal operação é capaz de transformar a indeterminação gerada pelo contínuo processo de complexificação social em possibilidades determinadas e determináveis, produzindo interpretações do mundo através de generalizações simbólicas. 
Já em entrevista concedida à $\mathrm{BBC}$ a respeito do que chamou "Ato profético pelo fim da corrupção e da crise econômica no Brasil”, Silas Malafaia afirmou que "o ato profético é para declarar que a corrupção vai acabar, que toda a bandalheira vai ser exposta”. Ao ser indagado pelo jornalista sobre complexidade da promessa, o pastor argumenta: "Quando Israel vivia períodos de crise, levantava um profeta que dizia que viriam tempos de paz e prosperidade. E aquilo tudo mudava. Então nós conhecemos essa prática”. Outro líder religioso, Estevam Hernandes, bispo da Igreja Renascer em Cristo e idealizador da Marcha para Jesus na cidade de São Paulo, abriu a edição de 2017 do evento com a oração: "Pai, tira a fome e a corrupção. O Deus de paz vai esganar (sic) o Satanás sob os teus pés (...)”. E continua: "É por isso esse clamor, por isso oramos para que a corrupção tenha um fim. Ela [corrupção] destrói o ser humano, tira suas expectativas e seus sonhos”. No mesmo evento, declara: “A oração inicial foi para mostrar que só ela mesmo, a oração, para quebrar esse ciclo de corrupção que estamos enfrentando no país”.

\section{Os evangélicos encontram Bolsonaro - afinidades eletivas: à guisa de conclusão}

Como última parada deste artigo ressaltaremos o encontro entre o discurso conservador religioso e um candidato capaz de transformá-lo de pauta em realidade. A relação entre Bolsonaro e os evangélicos não deve ser vista como simples arranjo de pastores que usam o discurso moral em um típico caso de coronelismo religioso. Existem fraturas que atravessam esferas econômicas, políticas e sociais já foram elucidadas. Porém, é importante neste ponto identificar alguns pontos da trajetória que aproximou Bolsonaro e o discurso conservador religioso.

A reportagem da Revista Época "Costura política que uniu Bolsonaro aos evangélicos" (2018) mostra que a composição entre setores evangélicos, conservadorismo e a eleição de Bolsonaro não é um fenômeno recente. Em 2006 o então deputado federal Jair Bolsonaro (PP) se aproximou do pastor Silas Malafaia, durante a tramitação do Projeto de Lei n. 122 na Câmara de Deputados que 
criminalizava a homofobia. Na época Bolsonaro comentou com o típico tom jocoso que conquistaria seus seguidores: "Tem de ter também uma lei que criminaliza a carecofobia, a flamengofobia” (ÉPOCA, 2018). Mesmo o projeto aprovado pela Câmara dos Deputados e arquivado no Senado, o evento foi um sinal dos tempos anunciando a relação entre Bolsonaro e a Bancada Evangélica. O discurso conservador, já em curso nas performances de políticos como Marco Feliciano e lideranças do meio evangélico pentecostal como Silas Malafia, ganharia cada vez mais espaço nas gramáticas políticas, pari passu o desgaste petista.

Neste bojo, a eleição do pastor Marcos Feliciano para a Comissão Parlamentar de Direitos Humanos em 2011 representou uma frente de batalha na relação entre parlamentares e atores religiosos em torno da mobilização de demandas morais. Em depoimento para a reportagem da Época (2018), Marcos Feliciano afirmou, valorizando sua posição: "Bolsonaro soube surfar nessa onda, teve o timing perfeito" (ÉPOCA, 2018). A polêmica do "kit gay" é o ponto alto desta escalada quando, em 2011, o então deputado Jair Bolsonaro conseguiu a aprovação da convocação do ministro da educação, Fernando Haddad, para explicar a cartilha na Comissão de Direitos Humanos comandada por Feliciano. Cedendo as pressões dos grupos conservadores, o governo Dilma veta a distribuição do material didádico, o que não impediu que a iniciativa do projeto escola sem homofobia - não existiu "kit gay" - fossem requentadas e retomadas contra Fernando Haddad em 2018, usadas para atacar o então candidato a presidente.

Desde então, empoderados por sua maior legitimidade e pelo desgaste do governo, atores políticos e religiosos passaram a surfar na onda da moralidade, como Silas Malafaia que afirmava estar "abrindo os olhos da igreja" para os projetos "demoníacos" do PT (ÉPOCA, 2018), em uma produção discursiva em torno de pautas morais que o consagrou como liderança evangélica na "briga ideológica contra o PT". No entanto, o passo decisivo para se tornar uma espécie de Cardeal de Richelieu, ainda estava por ser dado, acontecendo em 2013, quando celebrou o casamento de Jair Bolsonaro e Michele, evangélica batista. 
Tal como havia acontecido no apoio a Lula, Malafaia foi um dos primeiros pastores a apostar em Bolsonaro como capaz de concretizar as demandas evangélicas, que agora eram de outra ordem. A adesão de outras lideranças, vale lembrar, como o bispo Edir Macedo, só viria em outubro e de forma valiosa, vale recordar a transmissão da entrevista do candidato durante o debate eleitoral em 4 de outubro de 2018, criando um mal estar com a justiça eleitoral, que negou cancelamento que acusava de favorecimento pela emissora. Tal controvérsia trouxe à tona as críticas do bispo da Sara Nossa Terra, Robson Rodovalho, reivindicando o direito de expressão dos evangélicos através do discurso de identidade minoritária: "Por que só pastores? E os cantores, os artistas que têm o seu público? Estão cerceando apenas um segmento" (ÉPOCA, 2018).

Por outro lado, ocorreram casos de divergências entre fiéis que sofreram hostilidades em suas congregações decorrentes de conflitos em redes sociais, por grupos de WhatsApp e também no púlpito. O pastor presbiteriano e presidente da ONG Rio de Paz, Antônio Carlos Costa, afirma receber mensagens de pessoas do país inteiro escandalizadas com a postura de seus pastores, que "praticamente obrigaram” o voto em Bolsonaro. Outros como a Igreja Renascer, que expulsou pastores locais que se recusaram a pregar em apoio ao candidato.

Os reflexos não se restringem aos arraias pentecostais, mas entre as denominações históricas conflitos marcaram o apoio a Bolsonaro. Em uma Igreja Presbiteriana no interior de São Paulo, um fiel relata ter presenciado "escandalizado", pessoas em um evento da sua congregação que "chamavam Bolsonaro de mito, faziam gesto da arma para cima e depois iam orar". Outro caso mostrava, através de mensagens de WhatssApp, obtidas pela reportagem, um pastor batista da Região dos Lagos, no Rio de Janeiro, orientava seus fiéis:

Eu estive fazendo uma pesquisa aqui, não quero obrigar meus irmãos a votarem nesses candidatos. Mas quero passar uma cola para os irmãos que me pediram. Penso que Bolsonaro seria um bom presidente. Bolsonaro 17. Segundo, governador do estado do Rio de Janeiro. O Wil Wetzel, digo, Witzel, vai fazer um bom governo", afirma o pastor. "Para senador, Flávio Bolsonaro, filho do Bolsonaro, 177. (ÉPOCA, 2018). 
Por último e não menos importante, a adesão de uma das mais antigas denominações pentecostais do país, a Assembleia de Deus, em evento na sede da denominação em Belém, Zona Leste de São Paulo (10 de outubro de 2018), quando o pastor José Wellington pediu a milhares de fiéis o voto em Bolsonaro lançando a campanha de oração "Igreja de joelho, Nação em pé".

Assim, a proeminência de Bolsonaro parece ter inflamado a produção discursiva dos evangélicos na esfera pública. Destacamos a entrevista de Michele Bolsonaro durante a campanha em 2018, quando se identificou genericamente como evangélica. Em sua fala, pululavam expressões da gramática evangélica: "Deus", "Família" e "Igreja", articulavam-se em uma espécie de dialeto "crentês", já bem corrente e capaz de mobilizar os sujeitos em torno desse discurso. Depois das eleições, Michele, em entrevista para a Rede Record, novamente ao se declarar evangélica, afirma que sua condição de primeira dama "era um propósito que o Senhor colocava em sua vida", a frase reflete bem o sentido do ser evangélico.

Não por acaso, foi na igreja da primeira-dama, Igreja Batista Atitude localizada na Barra da Tijuca, zona oeste do Rio de Janeiro-, que o candidato Jair Bolsonaro foi recebido durante campanha, retornando após a vitória no pleito, quando agradeceu aos fiéis e recebeu a oração do pastor Josué Valandro Jr, que repete novamente a noção de "propósito", usada por Michele:

Que ninguém consiga desfazer o propósito melhor para a nossa nação. Capacita Jair Bolsonaro. E que em outubro tenhamos uma resposta do céu sobre a vida do teu filho. E querendo, Senhor, no dia $1^{\circ}$ de janeiro, este seu filho suba a rampa do Planalto para começar uma nova história do Brasil. (ÉPOCA, 2018).

A vitória de Bolsonaro também foi motivo de comemoração em outras igrejas evangélicas. $\mathrm{O}$ resultado das urnas foi anunciado em pleno do culto na Assembleia de Deus Vitória em Cristo (ADVEC), no bairro da Penha, subúrbio do Rio de Janeiro. Na ocasião, a notícia da eleição de Bolsonaro levou a igreja ao êxtase, enquanto exibiam a bandeira nacional no telão do altar e os fiéis aplaudiam com salvas de "glória". Semanas seguintes o presidente foi recebido no mesmo altar 
e ovacionado como "mito!", enquanto o pastor Silas Malafaia, orando, declarava: “Aqui está uma pessoa comprometida com os valores da família cristã!", claramente evocando enunciados da gramática moral mobilizada pelo governo.

Certamente, tais cenas parecem confirmar as proposições sobre os evangélicos como principais protagonistas do conservadorismo, apesar de termos também setores evangélicos progressistas, como os evangélicos ecumênicos e históricos que apoiaram Guilherme Boulos (PSOL) e Fernando Haddad (PT). Nem só de conservadorismo são constituídos os evangélicos hoje. O pastor Henrique Vieira da Igreja Batista do Caminho participou ativamente durante as eleições em 2018 em atos ao lado dos candidatos de esquerda - assim como, em manifestações decorrentes do assassinato da Marielle Franco - são exemplos. Em suas redes sociais é recorrente o discurso afirmando que "nem todo evangélico é conservador", uma disputa clara pelo significante evangélico.

No entanto, a urdidura do conservadorismo dentro das igrejas evangélicas veio crescendo e tomando corpo lentamente, em pesquisas anteriores, já podemos notar a relação entre o comportamento dos evangélicos e o discurso conservador. “Ah eles vão ensinar sexo pro meu filho na escola”, comentavam duas jovens as vésperas da das eleições municipais no Rio de Janeiro entre Marcelo Crivella (PRB) e Marcelo Freixo (PSOL) em 2016 (GRACINO JUNIOR e REZENDE, 2020). A cena ocorreu na saída de um culto na Igreja Metodista em Brás de Pina, subúrbio do Rio de Janeiro, quando uma das jovens perguntou a amiga sobre a escolha do candidato. A moralidade expressa no discurso "nós" e "eles" revela o conservadorismo que encontra recepção entre os evangélicos.

Sem negar a importância da identidade denominacional, tais controvérsias públicas (MONTERO, 2015) parecem reunir a identificação dos evangélicos através de discursos que associam o "ser evangélico" ou "crente" às pautas morais. Neste sentido, não podemos ignorar os afetos políticos mobilizados em torno da moralidade religiosa dos evangélicos durante as eleições de 2018. Se o voto evangélico foi decisivo ou não, a referência bíblica no lema da campanha e as 
narrativas acima indicam que temos um discurso evangélico que se identifica com as pautas morais e reforçam a disputas e tensões em torno desta identidade. Neste caso é importante identificar como demandas morais refletem pontos nodais que referendam um aparato discursivo que cria essa narrativa genérica em torno dos “evangélicos” como ator político no espaço público.

Consideramos aqui que a crescente força política de candidatos-pastores através de pautas conservadoras é um dado importante. Elas reforçam a ideia de que é possível uma identificação através dos discursos em defesa da moralidade como elementos que mobilizam afetos traduzidos pela agenda política da onda conservadora, unindo sujeitos através de emoções como indignação ou o desamparo, ultrapassando as formas racionais de sociabilidade modernas (SAFATLE, 2017). Diante da falência dos projetos de racionalidade, como os casos limitados da cidadania pelo consumo nos governos petistas, as normatividades sociais passam a ser configuradas nos “corpos políticos” que são mobilizados por circuitos impessoais de afetos, como lembrou Safatle (2016, p. 14). É neste sentido que o "medo" e "desamparo" estão relacionados aos afetos morais que atravessados pelo antagonismo mundo-igreja, traduzidos pelas disputas em torno de moralidades como a preservação da família diante das ameaças "mundanas”, presentes típicos do universo religioso evangélico, mobilizam setores conservadores através de demandas morais.

\section{REFERÊNCIAS}

ALMEIDA, Ronaldo de. Bolsonaro presidente: conservadorismo, evangelismo e a crise brasileira. Novos Estudos Cebrap, São Paulo, v. 38, n. 1, p. 185-213, abr. 2019.

ALMEIDA, Ronaldo. A onda quebrada - evangélicos e conservadorismo. Cadernos Pagu, Campinas, n. 50, 2017. Disponível em:

https://www.scielo.br/scielo.php?script=sci_arttext\&pid=So10483332017000200302\&lng=pt\&tlng=pt. Acesso em: 6 ago. 2020.

ALONSO, Ângela. A política das ruas: protestos em São Paulo de Dilma a Temer. Novos Estudos Cebrap, São Paulo, p. 49-58, jun. 2017. 
ALONSO, Ângela. Orelha. In: Toniol, Rodrigo e Almeida, Ronaldo. Conservadorismo, fascismo e fundamentalismo: análises conjunturais. Campinas: Editora Unicamp, 2018.

ALVES, José Eustáquio Diniz. O voto evangélico garantiu a eleição de Jair Bolsonaro. EcoDebate, 31 out. 2018. Disponível em: https://www.ecodebate.com.br/2018/10/31/ovoto-evangelico-garantiu-a-eleicao-de-jair-bolsonaro-artigo-de-jose-eustaquio-dinizalves/. Acesso em: 6 ago. 2020.

AVRITZER, Leonardo et al. (org.). Corrupção: ensaios e críticas. Belo Horizonte: Editora UFMG, 2008.

BENEVIDES, Maria Victoria. A UDN e o udenismo: ambigüidades do liberalismo brasileiro (1945-1965). Rio de Janeiro: Paz e Terra, 1981.

BEYER, Peter. A privatização e a influência pública da religião na sociedade global. In: FEATHERSTONE, Mike (org.). Cultura global: nacionalismo, globalização e modernidade. Petrópolis: Vozes, 1999. p. 395-419.

BURDICK, John. Procurando Deus no Brasil: a Igreja Católica progressista no Brasil na arena das religiões urbanas brasileiras. Rio de Janeiro: Mauad, 1998.

BURITY, Joanildo. ¿ Ola conservadora y surgimiento de la nueva derecha cristiana brasileña? La coyuntura postimpeachment en Brasil. Ciencias Sociales y Religión / Ciências Sociais e Religião, Campinas, v. 22, p. 1-24, 2020.

BURITY, Joanildo. A onda conservadora na política brasileira traz o fundamentalismo ao poder? In: TONIOL, Rodrigo; ALMEIDA, Ronaldo. Conservadorismo, fascismo e fundamentalismo: análises conjunturais. Campinas: Editora Unicamp, 2018.

BURITY, Joanildo; MACHADO, Maria das Dores Campos (org.). Os votos de Deus: evangélicos, política e eleições no Brasil. Recife: Massangana, 2006.

CAMPOS, Leonildo Silveira. Teatro, templo e mercado: organização e marketing de um empreendimento neopentecostal. Petrópolis: Vozes; São Paulo: Simpósio Editora: UMESP, 1997.

CARVALHO, José Murilo de. Passado, presente e futuro da corrupção à brasileira. In: AVRITZER, Leonardo et al (org.). Corrupção: ensaios e críticas. Belo Horizonte: UFMG, 2008. p. 237-242.

CARVALHO, Laura. A valsa brasileira: do boom ao caos econômico. São Paulo: Todavia, 2018.

CHATTERJEE, P. The politics of the governed: reflections on popular politics in most of the world. New York: Columbia University Press, 2004.

CHAUÍ, Marilena. Sobre o Medo. In: CARDOSO, Sérgio (org.). Os sentidos da paixão. São Paulo: Companhia das Letras, 2002. 
CODATO, Adriano Nervo; OLIVEIRA, Marcus Roberto de. A marcha, o terço e o livro: catolicismo conservador e ação política conjunta de golpe de 1964. Revista Brasileira de História, São Paulo, v. 24, n. 47, p. 271-302, 2004.

CONNOLLY, William E. Some theses on secularism. Cultural Anthropology, v. 26, n. 4, p. 648-656, 2011.

CORTES, Mariana. O mercado pentecostal de pregações e testemunhos: formas de gestão do sofrimento. Religião \& Sociedade, Rio de Janeiro, v. 34, n. 2, p. 184-209, 2014.

D’EPINAY, Christian Lalive. O refúgio das massas. Rio de Janeiro: Paz e Terra, 1970.

DARDOT, Pierre; LAVAL, Christian. A nova razão do mundo: ensaio sobre a sociedade neoliberal. São Paulo: Editora Boitempo, 2016.

ÉPOCA. A costura política que uniu Bolsonaro aos evangélicos. 6 nov. 2018. Disponível em: https://epoca.globo.com/a-costura-politica-que-uniu-bolsonaro-aosevangelicos-23211834. Acesso em: 6 ago. 2020.

FERNANDES, Rubem César. Conservador ou progressista, questão de conjuntura. Religião e Sociedade, Rio de Janeiro, n. 9, p. 59-62, jul. 1983.

FONSECA, Alexandre Brasil. Foram os evangélicos que elegeram Bolsonaro? IHU Unisinos. 7 nov. 2018. Disponível em: http://www.ihu.unisinos.br/584446-foram-osevangelicosque-elegeram-bolsonaro: Acesso em: 6 ago. 2020.

FOUCAULT, Michel. Nascimento da biopolítica (1978-1979). São Paulo: Martins Fontes, 2008.

FRY, Peter; HOWE, Gary. Duas respostas à aflição: umbanda e pentecostalismo. Debate e Crítica, São Paulo, n. 6, p. 75-94, 1975.

GAGO, Verónica. A razão neoliberal: economias barrocas e pragmática popular. São Paulo: Editora Elefante, 2018.

GIUMBELLI, Emerson. O fim da religião: dilemas da liberdade religiosa no Brasil e na França. São Paulo: Attar Editorial, 2002.

GOETHE, J. As afinidades eletivas. Tradução de Erlon José Paschoal. São Paulo: Nova Alexandria, 2008.

GRACINO JUNIOR, Paulo. A demanda por deuses: globalização, fluxos religiosos e culturas locais nos dois lados do Atlântico. Rio de Janeiro: EdUERJ, 2016.

GRACINO JUNIOR, Paulo. Surtos de aconselhamento e soluções biográficas? A Igreja Universal e a nova face do fenômeno religioso na sociedade contemporânea. Revista Anthropológicas, Recife, v. 1, p. 32-54, 2008. 
GRACINO JUNIOR, Paulo; TARGINO, Janine; REZENDE, Gabriel S. Confiança institucional e opinião pública entre jovens religiosos na cidade do Rio de Janeiro.

Interseções: revista de estudos interdisciplinares, Rio de Janeiro, v. 20, p. 305-329, 2018.

HABERMAS, Jürgen. Entre naturalismo e religião. Rio de Janeiro: Tempo Brasileiro, 2007.

HIRSCHMAN, Alberto. As paixões e os interesses: argumentos políticos para o capitalismo antes de seu triunfo. Rio de Janeiro: Paz e Terra, 2002.

JARDIM, Willelm Martins Andrade. Religião e política na Igreja Universal do Reino de Deus: um estudo das campanhas eleitorais de 2010 e 2014. Monografia (Ciências Sociais) - Universidade Federal de Viçosa, 2017.

JOAS, Hans. A sacralidade da pessoa: nova genealogia dos direitos humanos. São Paulo: Editora Unesp, 2012.

LACLAU, Ernesto. Emancipação e diferença. Rio de Janeiro: EdUERJ, 2011.

LACLAU, Ernesto. Identity and hegemony: the role of universality in the constitution of political logics. In: BUTLER, J.; LACLAU, E.; ZIZEK, S. Contingency, hegemony, universality: contemporary dialogues on the left. London: Verso, 2000. p. 44-89.

LACLAU, Ernesto; MOUFFE, Chantal. Hegemonia e estratégia socialista: por uma política democrática radical. São Paulo: Intermeios, 2015.

LÖWY, Michael. A jaula de aço: Max Weber e o marxismo weberiano. Tradução de Mariana Echalar. São Paulo: Boitempo Editorial, 2014.

LUHMANN, Niklas. La religión de la sociedad. Madri: Editorial Trotta, 2007.

MACHADO, M. D. C. et al. (org.). Religiões e homossexualidades. Rio de Janeiro: Fundação Getúlio Vargas, 2010.

MACHADO, M. D. C. Expansão e ativismo político de grupos evangélicos conservadores: secularização e pluralismo em debate. Civitas: revista de ciências sociais, Porto Alegre, v. 16, n. 4, p. 708-726, 2016.

MACHADO, M. D. C. Representações e relações de gênero nos grupos pentecostais. Estudos Feministas, Florianópolis, v. 13, n. 2, p. 425-436, 2005.

MACHADO, Maria das Dores Campos Machado; BURITY, Joanildo. A ascensão política dos pentecostais na avaliação de líderes religiosos. Dados, Rio de Janeiro, v. 57, p. 601629, 2014.

MAINWARING, Scott. Igreja Católica e política no Brasil: 1916 - 1985. São Paulo: Brasiliense, 1985. 
MARIANO, Ricardo. A reação dos evangélicos ao novo código civil. Civitas: revista de ciências sociais, Porto Alegre, v. 6, n. 2, p. 77-99, 2006.

MARIANO, Ricardo; GIARDI, Dirceu A. Eleições presidenciais na América Latina em 2018 e ativismo político de evangélicos conservadores. Revista USP, São Paulo, n. 120, p. 6176, 2019.

MARIANO, Ricardo; PIERUCCI, Antônio Flávio. O envolvimento dos pentecostais na eleição de Collor. Novos Estudos Cebrap, São Paulo, v. 34, p. 92-100, 1992.

MARIZ, Cecília. Alcoolismo, gênero e pentecostalismo. Religião e Sociedade, Rio de Janeiro, v. 16, n. 3, p. 80-93, 1994.

MARIZ, Cecília. Coping with poverty: pentecostals and base communities in Brazil. Philadelphia, USA: Temple University Press, 1994.

MARIZ, Cecília; GRACINO JUNIOR, Paulo; MESQUITA, Wânia. Os jovens e a religião na sociedade contemporânea. Revista Interseções, Rio de Janeiro, v. 20, n. 2, p. 261-267, 2018.

MARIZ, Cecília; MACHADO, Maria D. Sincretismo e trânsito religioso: comparando carismáticos e pentecostais. Comunicações do Iser, Rio de Janeiro, ano 13, n. 45, p. 2434, 1994 .

MAZUMDAR, Surajit. Neo-Liberalism and the rise of right-wing conservatism in India. Desenvolvimento em Debate, v. 5, n. 1, p. 115-131, 2017.

MENDONÇA, Daniel de. Como olhar "o político" a partir da teoria do discurso. Revista Brasileira de Ciência Política, Brasília, n. 1, p. 153-169, jan.-jun. 2009.

MENDONÇA, Daniel de; RODRIGUES, Léo Peixoto. Pós-estruturalismo e teoria do discurso em torno de Ernesto Laclau. Porto Alegre: EDIPUCRS, 2014.

MENDONÇA, Daniel de; RODRIGUES, Léo Peixoto; LINHARES, Bianca (org.). Ernesto Laclau e seu legado transdisciplinar. São Paulo: Intermeios, 2017.

MIGUEL, Luís Felipe. Os sentidos do Lulismo: reforma gradual e pacto conservador, de Singer, André. Novos Estudos Cebrap, São Paulo, v. 95, p. 157-163, 2013.

MIGUEL, Luís Felipe; BIROLI, Flávia. Introdução: teoria e política na crise da democracia. In: MIGUEL, Luís Felipe; BIROLI, Flávia (org.). Encruzilhadas da democracia. Porto Alegre: Zouk, 2017. v. 1, p. 7-11.

MONTERO, Paula. "Religiões públicas” ou religiões na esfera pública? Para uma crítica ao conceito de campo religioso de Pierre Bourdieu. Religião e Sociedade, Rio de Janeiro, v. 36, n. 1, p. 128-150, 2016.

MONTERO, Paula. Controvérsias religiosas e esfera pública: repensando as religiões como discurso. Religião e Sociedade, Rio de Janeiro, v. 32, n. 1, p. 167-163, 2012. 
MOUFFE, Chantal. Democracia, cidadania e a questão do pluralismo. Revista Política \& Sociedade, Florianópolis, n. 3, p. 11-23, out. 2003.

MOUFFE, Chantal. Sobre o político. São Paulo: Martins Fontes, 2015.

NATALUCCI, A. Mobilização social e mudanças políticas: revisitando o conceito de gramáticas de ação política. Plural, São Paulo, v. 22, n. 1, p. 83-106, 2015.

NOVAES, Regina. Os escolhidos de Deus: trabalhadores, pentecostais e cidadania. Rio de Janeiro: Marco Zero, 1985.

OLIVEIRA, Isabel de Assis Ribeiro de. O mal-estar contemporâneo na perspectiva de Charles Taylor. Revista Brasileira de Ciências Sociais, São Paulo, v. 21, n. 60, p.135145, 2006.

ORTEGA, Francisco. Genealogias da amizade. São Paulo: Editora Iluminuras, 2002.

PIERUCCI, Antônio Flávio. As bases da nova direita. Novos Estudos Cebrap, São Paulo, v. 19, p. 26-45, 1987.

PIERUCCI, Antônio Flávio. Representantes de Deus em Brasília: a bancada evangélica na Constituinte. Ciências Sociais Hoje, São Paulo, p. 104-132, 1989.

PINHEIRO-MACHADO, Rosana; SCALCO, Lúcia Mury. Da esperança ao ódio: juventude, política e pobreza do Lulismo ao Bolsonarismo. Cadernos IHUideias, São Leopoldo, v. 16, p. 3-15, 2018.

PRA, Jussara Reis; EPPING, Léa. Cidadania e feminismo no reconhecimento dos direitos humanos das mulheres. Revista Estudos Feministas, Florianópolis, v. 20, p. 33-51, 2012.

PRZEWORSKI Adam. Capitalismo e social-democracia. São Paulo: Companhia das Letras, 1989.

PY, Fábio. Cristologia cristofascista de Bolsonaro. Instituto Humanitas Unisinos, São Leopoldo, p. 1-9, 8 jun. 2019.

RANCIÈRE, Jacques. O ódio à democracia. São Paulo: Boitempo, 2014.

RIZEK, Cibele. Faces do Lulismo: políticas de cultura e cotidiano na periferia de São Paulo. In: SINGER, André; LOUREIRO, Isabel (org.). As contradições do Lulismo: a que ponto chegamos? São Paulo: Boitempo Editorial, 2016. p. 185-219.

ROLIM, Francisco Cartaxo. Pentecostalismo, governos militares e revolução. Revista Eclesiástica Brasileira, Rio de Janeiro, v. 210, p. 324-348, jun. 1993.

SAFATLE. Vladimir. O circuito dos afetos: corpos políticos, desamparo e o fim do indivíduo. Belo Horizonte: Autêntica Editora, 2017. 
SALLUM JÚNIOR, Brasílio João; KUGELMAS, Eduardo. Sobre o modo Lula de governar. In: SALLUM JÚNIOR, Brasílio João; KUGELMAS, Eduardo. Brasil e Argentina hoje: política e economia. Bauru: EDUSC, 2004.

SANCHIS, Pierre. Pluralismo, transformação, emergência do indivíduo e de suas escolhas. IHU On-Line, São Leopoldo, ano 12, n. 400, p. 5-7, 27 ago. 2012.

SENNETT, Richard. O declínio do homem público: as tiranias da intimidade. São Paulo: Companhia das Letras, 1999.

SILVA, Mayra Goulart. O Populismo para além de Laclau: entre a expansão do demos e a desfiguração do liberalismo. Revista Estudos Políticos, Campina Grande, v. 9, n. 1, p. 49-70, 2019.

SILVEIRA, Diego Omar da. Mulher, mãe e esposa: conservadorismo católico e representações do feminino na imprensa católica mineira. Pro-Posições, Campinas, v. 28, n. 3, p. 330-352, dez. 2017.

SINGER, André. Os sentidos do Lulismo: reforma gradual e pacto conservador. São Paulo: Companhia das Letras, 2012.

SINGER, André; LOUREIRO, Isabel (org.). As contradições do Lulismo: a que ponto chegamos? São Paulo: Boitempo Editorial, 2016. p. 185-219.

SINGER, Paul. Dominação e desigualdade. São Paulo: Paz e Terra, 1981.

SMITH, Amy Erica. Religion and Brazilian democracy: mobilizing the people of God. Cambridge: Cambridge University Press, 2018.

SMITH, Christian S. (org.). The secular revolution: power, interests, and conflict in the secularization of American public life. Berkeley: University of California Press, 2003.

SMITH, Christian S. American evangelicalism: embattled and thriving. Chicago: The University of Chicago Press, 1998.

SOUZA, André Ricardo de; PINTO, Marilina Conceição Oliveira Serra. Duas igrejas expoentes do novo empreendedorismo pentecostal. Contemporânea: revista de sociologia da UFSCar, São Carlos, v. 3, n. 1, jan.-jun. 2013.

TAYLOR, Charles. A ética da autenticidade. São Paulo: É Realizações, 2011.

TAYLOR, Charles. As fontes do self: a construção da identidade moderna. São Paulo: Edições Loyola, 1994.

WEBER, M. A ética protestante e o espírito do capitalismo. São Paulo: Companhia das Letras, 2004. 